\title{
Trade Imbalance and Entrepreneurial Activity: A Quantitative Panel Data Analysis
}

\author{
Ojeaga Paul I. \\ Oshadare Segun A. \\ Akinbola Olufemi A. \\ Ajayi J, A. \\ Federal University of Agriculture, Abeokuta, Nigeria.
}

\begin{abstract}
Shale Oil export from the United States overseas today depicts the need for the United States to reduce its negative trade balance sheet and Nigeria's wish to improve agricultural exports reflects its willingness to reduce its problem of oil dependence. Net Savings accruing from exporting capabilities have strong consequences for trade and specifically for balance of payment and country specific trade account. Its positive effect on net trade is often affected by strong domestic consumption of foreign imports leading to trade imbalances, and capital flight. This study investigates the relationship between savings, exports and net trade using quantitative techniques by considering panel data for Nigeria and the United States, It was found that net savings from trade and exports promote net trade positively, and that imports affects net trade negatively since business were probably not importing to promote further production activities causing trade deficit and negative imbalance.
\end{abstract}

KEYWORDS: Trade, Net Trade Exports, Imports Industrial Activity and Entrepreneurship

\subsection{Introduction}

World Bank data 2015 depict that merchandise trade i.e. trade in processed and unprocessed commodities are on the increases in Nigeria and the United States. The export of shale oil from the United States has now made United States an oil exporter rather than a chief importer. Nigeria also seeks to diversify its economy away from oil and primary commodities but has met little success in that direction,

The study investigates the effect of entrepreneurial activity resulting from merchandise exports and imports on trade imbalance The reason for the study is that trade imbalance is becoming an issue in many countries, driving up budget deficit and limiting ability of governments to spend on capital projects, therefore the study intends to investigate the consequences of entrepreneurial activity on trade imbalances for the United States and Nigeria. Merchandise trade consists of all trade in commodities and processed materials in countries. It can account for a strong part of industrial processed and semi processed commodities, flowing to both domestic and international markets. The questions, this study investigates includes: what part of international merchandise trade is responsible for negative trade imbalance across countries? And secondly are other factors responsible for negative trade imbalance across countries? And finally what is the effect of net savings in countries on trade imbalance in general?

Trade has strong implications for both exporting and importing countries. Exports improve net savings, boost economic growth and often create employment in exporting countries. Exports also has strong positive effects on foreign exchange earnings and a nation's balance of payment improving the nation's net trade and overall well being of the domestic economy. Imports also help countries in making up for deficiencies in availability of raw and factory materials and reduce cost of engaging in sectors that are deemed not likely to be of strategic or of comparative advantage thereby cutting cost and reducing wastages, Many factors are known to affect trade some include conditions in import destination countries,

http://dx.doi.org/10.19085/journal.sijbpg041101 
cost of transportation, access to capital to importers as well as exporters, country specific monetary economic policy, nature of industrial activity in exporting and importing countries and finally domestic household consumption pattern across exporting and importing countries.

The study investigates the effect of merchandise trade specifically merchandise exports and imports on net trade across countries. Net trade of a country is actually the difference between its exports and imports. Net trade for the sake of the study is used to capture trade imbalance therefore allowing for an analysis of the effect of merchandise trade activities on trade imbalance. The generalized method of moment (GMM) is used in conjunction with the ordinary least squares (OLS) estimation techniques due to the likelihood of endogeneity of the net savings variable. The rest of the study is divided into the literature review, the data and methodology, results and presentation and finally the discussion and conclusive sections.

\subsection{Short Literature Review}

Lee 1995 states that increased inputs of capital and intermediate goods which are not available domestically often results in rise of productivity levels. Active participation in international trade through increase in exporting can improve competition and productivity in exporting countries Wagner (2007). Outward oriented developing countries are also likely to achieve more rapid growth and development, making countries that participate in international trade to develop faster than inward oriented countries Dollar (1992).

International trade has also been found to contribute to technological diffusion; therefore outward looking countries often take advantage of the benefits from international trade to acquire technology and innovation Keller (2001). International trade also provides platforms for supporting technology spillovers impacting productivity levels positively Saggi (2000). Participation in international trade also forces countries to improve their trade laws and forge cooperation with other countries, a case is that of the conditionality for China joining the World Trade Organization (WTO) Cross (2004).

Parametric and non parametric methods have been used in the study of productivity and trade. According to Oh et al (2008), non parametric approach using indexes are easy to compute and analyze. This empirical study utilize parametric estimation techniques such as the Ordinary Least Squares (OLS) and the Generalized Methods of Moments estimation techniques for the study on net trade for Nigeria and the United States using panel data.

\subsection{Data and Methodology}

All data used in the study are obtained from the data market of Iceland. Data market of Iceland obtains its data from World Bank Data and the Federal Reserve Bank of America. Panel data for a period of 35 years from 1980 to 2015 for Nigeria and the United States was utilized in the study. They include net trade, merchandise exports, merchandise imports, domestic household consumption, money supply, direct capital flow to the private sector, and gross savings and net savings all in United States Dollars (USD),

The dependent variable in the study is net trade (net trade) which is the measure of trade balance and a difference between exports and imports), this was used to capture trade balance, other explanatory variables include merchandise exports which captures exports in commodities and goods (mexports), merchandise imports (mimports), domestic household consumption (hcons), money supply (ms) which captured country specific monetary policy which affect interest rest, gross and net savings (gsavings and nsavings) and finally direct capital flow to the private sector (dcps). The study insist on merchandise exports and imports since this reflects entrepreneurial activity through trade and utilizes both gross and net savings to understand what component of savings count in the study of the dynamics of trade.

The preferred method of estimation used in the study is the generalized method of moments (GMM) estimation although ordinary least squares (OLS) was also used for studies specifically for Nigeria and panel data results regressions using fixed and random effects are shown for all data to compare its quality with that of that of the GMM. The study for Nigeria and the United States is conducted owing to the similar 
policy towards promoting manufacturing and reducing trade deficits by both current administration in Nigeria and the United States. In the study the exports variable will also be expressed as:

Exports $f$ (Natural Resources, Technology and Innovation, Cost of Production and Transport)

Imports can also be expressed as

Imports f(Industrial Demands, Domestic Consumption, and Natural Resources)

With exports and imports been function of specific variables. The above now allows us to express the

following equations

\section{EQN. (1.) $\quad H S C=I N C O M E+P R O D C O S T+I M P C O S T$}

Where household domestic consumption (HSC) is determined by household income, cost of production (PRODCOST) and cost of imports (IMPCOST) since consumers will shop based on their wages and the quantity consumed will be a function of price of goods at the market while cost of import will affect consumer choice of choosing between domestic or foreign goods.

EQN. (2.) MS = MARKLQ + CAPCOST+ MPOL

While money supply (MS), will be affected by market liquidity ratio (MARKLQ), cost of accessing capital (CAPCOST) and finally country specific monetary policy (MPOL), this will be because money supply being a Central Bank controlled variable will portray country specific monetary policy control as it affects the cost of lending to the private sector.

$E Q N$. (3.) $D C P S=C A P C O S T+M S+L P$

Direct capital flow to the private sector will be affected by country specific bank lending policy (LP), money supply which measure amount of free capital available to commercial banks for lending and finally the cost of accessing capital such as commercial bank lending interest rates (CAPCOST).

\section{EQN. (4.) EXPORTS = PRODCOST + TARIFFS + IMPCOST+INTMARKETS}

Exports volume will be determined by the cost of domestic production (PRODCOST), tariffs (TARIFFS) in this case both domestic and foreign, cost of imports (IMPCOST) which is likely to affect consumer choice of consumption between domestic and foreign goods and finally conditions in the international markets (INTMARKETS) that affect export receptivity and price.

\section{EQN. (5.) IMPORTS = DOSMARKETS+ TARIFFS + PRODCOST}

Imports will also be determined by conditions in the domestic markets (DOSMARKETS) of the importing country, cost of tariffs (TARIFFS) in international trade between importing and exporting countries and finally the cost of production (PRODCOST) in the originating country of commodities imported.

\section{EQN. (6) NETTRADE = HSC+SAVINGS+ EXPORTS + IMPORTS+MPOL+CAP}

Finally net trade (NETTRADE) will be determined by household domestic consumption (HSC), national savings (SAVINGS), exports (EXPORTS), imports (IMPORTS), country specific monetary policy (MPOL) in the case of this study captured using money supply and capital (CAP). .In the study net trade is expressed as

Net trade $f$ (household consumption, savings, exports, imports, money supply and capital)

This expresses net trade as a function of the above mentioned variables. Therefore the model to be estimated is one in which net trade will be a function of household consumption, savings, exports, imports, monetary policy and finally capital flow to private sector businesses expressed as

EQN. (7.) NETTRADE $E_{\text {it }}=\propto_{0}+\propto_{1}$ HSC $_{\text {it }}+\propto_{2}$ MEXPORTS $_{\text {it }}+\propto_{3}$ MIMPORTS $_{\text {it }}$ $+\propto_{4} S A V_{i t}+\propto_{5} M S_{i t}+\propto_{6} D C P S_{i t}+\epsilon_{i t}$ 
The suitability of the GMM are as follows a.) It allows for the control of multiple endogenous variables, and deals with issues of panel bias and fixed effects since the disturbance term $\varepsilon_{\mathrm{i} t}$ consist of the fixed effects $\mu_{i, t}$ and the idiosyncratic shocks $v_{i, t}$ Arrellano, Bond (1998), Doormik, Arellano ,Bond (2002) and Rood man (2006) , b.) Other merits of the GMM estimator include its usefulness in the control for long run effects and the estimates are robust even in the presence of heteroscedastic errors, c.) The inclusion of the lag of the dependent variable $\left(\alpha_{0}-1\right)$ as an explanatory variable and the use of the system GMM always includes all explanatory variable and their lag values as instruments to overcome the problem of the search for a suitable instrument Roodman (2006) provides further explanations.

\subsection{Results Presentation}

The ordinary least squares (OLS) results for Nigeria using times series data is presented in tables 1 and 5 respectively, miss specification test for Normality, auto correlation and model stability show that the OLS model is well specified although for brevity the results for test for normality are not presented. Merchandise exports (mexports) was found to contribute 81.9 percentage points to improvement in net trade having strong significant effect on net trade (nettrade) growth for Nigeria, while imports was found to have strong negative significant effect on net trade. Net savings (nsavings) for Nigeria was not improving net trade growth and capital to private sector enterprise has no significant effect on net trade growth. Household consumption (hcons) for Nigeria was found not to affect net trade growth with the likelihood of exports from oil and other mineral likely to crowd out domestic household consumption (hcons). Country specific monetary policies (captured using money supply (ms)) were also found not to affect net trade.

\section{Table 1. Net Trade OLS Regression Result for Nigeria}

\begin{tabular}{|c|c|c|c|c|c|c|}
\hline Source & SS & $d f$ & MS & & \multirow{4}{*}{\multicolumn{2}{|c|}{$\begin{array}{lr}\text { Number of obs } & =33 \\
\mathrm{~F}(8, \quad 24) & =11.96 \\
\text { Prob }>\mathrm{F} & =0.0000 \\
\text { R-squared } & =0.7994 \\
\text { Adj R-squared } & =0.7325 \\
\text { Root MSE } & =4.6 \mathrm{e}+0\end{array}$}} \\
\hline Model & $2.0002 e+21$ & \multirow{2}{*}{\multicolumn{2}{|c|}{$\begin{array}{rr}8 & 2.5003 \mathrm{e}+20 \\
24 & 2.0913 \mathrm{e}+19\end{array}$}} & & & \\
\hline Residual & $5.0191 \mathrm{e}+20$ & & & & & \\
\hline Total & $2.5021 \mathrm{e}+21$ & 327.81 & $2 e+19$ & & & \\
\hline nettrade & Coef. & Std. Err. & $\mathrm{t}$ & $P>|t|$ & [95\% conf. & |al] \\
\hline hcons & .001073 & .0372 & 0.03 & 0.977 & -.075704 & .0778499 \\
\hline gsavings & -.2978595 & .1672378 & -1.78 & 0.088 & $\begin{array}{l}-.6430214 \\
\end{array}$ & .0473024 \\
\hline nsavings & .102121 & 194959 & 0.52 & 0.605 & -.3002546 & .5044967 \\
\hline & $4.09 \mathrm{e}+07$ & $3.40 e+08$ & 0.12 & 0.905 & $-6.60 \mathrm{e}+08$ & $7.42 e+08$ \\
\hline mexports & .8188336 & .1589321 & 5.15 & 0.000 & .4908139 & 1.146853 \\
\hline mimports & $\begin{array}{l}-.7721329 \\
\end{array}$ & .3055768 & -2.53 & 0.019 & -1.402812 & $\begin{array}{l}-.1414534 \\
-.114\end{array}$ \\
\hline$d c p s$ & $-3.19 e+07$ & $4.22 e+08$ & -0.08 & 0.940 & $-9.03 e+08$ & $8.39 \mathrm{e}+08$ \\
\hline year & $-6.93 e+07$ & $2.66 e+08$ & -0.26 & 0.796 & $-6.18 e+08$ & $4.79 \mathrm{e}+08$ \\
\hline _cons & $1.37 \mathrm{e}+11$ & $5.29 e+11$ & 0.26 & 0.798 & $-9.55 e+11$ & $1.23 e+12$ \\
\hline
\end{tabular}

\section{Note: Authors Compilations from STATA 13}

Note: The above results show OLS results for Nigeria using time series data for Nigeria.

The results using panel data for Nigeria and the United States are shown in tables 2,3,4 and 6 respectively. Panel OLS regressions are run in tables 2 and 3 using fixed effect and random effect models respectively. In table 3 the generalized methods of moments estimation technique is utilized. The model is the preferred model as stated earlier since it allows for overcoming the problems of assumptions of distributional normality, endogeneity and controls for fixed effects.

The Housman test was also conducted to determine the mose suitable between the fixed and random effect model which is to be used for the study, the null hypothesis accepting the random effect model was accepted (with p-values 0.000). 
The OLS results for fixed effects show that imports has strong negative effect and merchandise exports (mexports) have strong positive effect on net trade using panel data for Nigeria and the United States (See table 2 with p-values 0.000 ) with merchandise exports contributing 87 percentage points to net trade growth. The panel data results of Nigeria and the United States for random effect show that exports have strong positive effect on net trade however in this case imports have no significant effect on net trade (See table 3 with p-values 0.000). This depicts the effect of controlling for fixed effect for both countries. Savings (net savings (nsaving) and gross savings (gsaving) ) have no significant effect on net trade using both the OLS fixed and random effect estimation technique allowing for the suspicion of the endogeneity of the savings variable and hence the utilization of the GMM estimation technique.

\section{Table 2. Net Trade Panel OLS Regression Result With Fixed Effects}

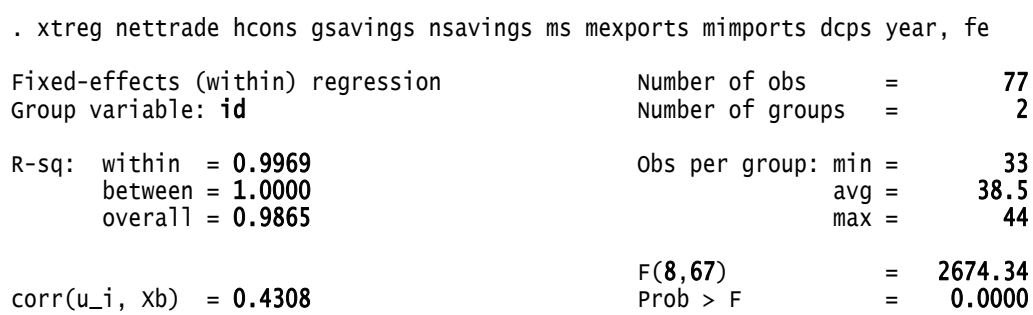

\begin{tabular}{r|rrrrrr}
\hline nettrade & Coef. & std. Err. & $\mathrm{t}$ & $\mathrm{P}>|\mathrm{t}|$ & [95\% Conf. Interva1] \\
\hline hcons & .0044375 & .0050265 & 0.88 & 0.380 & -.0055954 & .0144704 \\
gsavings & .004369 & .0118702 & 0.37 & 0.714 & -.019324 & .0280621 \\
nsavings & .0419705 & .1411342 & 0.30 & 0.767 & -.2397346 & .3236756 \\
ms & $-8.36 \mathrm{e}+07$ & $3.84 \mathrm{e}+08$ & -0.22 & 0.828 & $-8.49 \mathrm{e}+08$ & $6.82 \mathrm{e}+08$ \\
mexports & 1.234311 & .1798898 & 6.86 & 0.000 & .8752492 & 1.593372 \\
mimports & -1.018832 & .1479856 & -6.88 & 0.000 & -1.314212 & -.7234514 \\
dcps & $-6.55 \mathrm{e}+07$ & $4.77 \mathrm{e}+08$ & -0.14 & 0.891 & $-1.02 \mathrm{e}+09$ & $8.87 \mathrm{e}+08$ \\
year & $-1.73 \mathrm{e}+09$ & $2.68 \mathrm{e}+08$ & -6.47 & 0.000 & $-2.27 \mathrm{e}+09$ & $-1.20 \mathrm{e}+09$ \\
_cons & $3.41 \mathrm{e}+12$ & $5.28 \mathrm{e}+11$ & 6.47 & 0.000 & $2.36 \mathrm{e}+12$ & $4.47 \mathrm{e}+12$ \\
\hline sigma_u & $3.564 \mathrm{e}+10$ & & & & & \\
sigma_e & $1.085 \mathrm{e}+10$ & & & & & \\
rho & .91513862 & (fraction of variance due to u_i) & \\
\hline
\end{tabular}

$F$ test that all $u_{-} i=0: \quad F(1,67)=5.08 \quad$ Prob $>F=0.0275$

Note: Authors Compilations from STATA 13

Note: The above fixed effects OLS result show results using panel data for Nigeria and the United States

Table 3. Net Trade Panel OLS Regression Result With Random Effects

\begin{tabular}{|c|c|c|c|c|c|c|}
\hline \multicolumn{4}{|c|}{$\begin{array}{l}\text { Random-effects GLS regression } \\
\text { Group variable: id }\end{array}$} & \multicolumn{2}{|c|}{$\begin{array}{l}\text { Number of obs } \\
\text { Number of groups }\end{array}$} & $\begin{array}{r}77 \\
2\end{array}$ \\
\hline \multicolumn{4}{|c|}{ 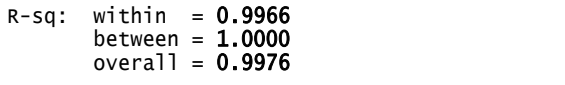 } & \multicolumn{3}{|c|}{ obs per group: $\begin{aligned} & \min = \\
& \operatorname{avg}= \\
& \max =\end{aligned}$} \\
\hline \multicolumn{4}{|c|}{$\begin{aligned} \text { Random effects } u_{-} i & \sim \text { Gaussian } \\
\operatorname{corr}\left(u_{-} i, x\right) & =0 \text { (assumed) }\end{aligned}$} & \multicolumn{2}{|c|}{$\begin{array}{l}\text { wald chi2(8) } \\
\text { Prob > chi2 }\end{array}$} & $\begin{array}{rr}= & 27821.09 \\
=\quad 0.0000\end{array}$ \\
\hline nettrade & Coef. & Std. Err. & z & $\mathrm{P}>|\mathrm{z}|$ & [95\% Conf & F. Interva1] \\
\hline $\begin{array}{r}\text { hcons } \\
\text { gsavings } \\
\text { nsavings } \\
\text { ms } \\
\text { mexports } \\
\text { mimports } \\
\text { dcps } \\
\text { year } \\
\text { _cons }\end{array}$ & $\begin{array}{r}-.0041829 \\
.0110839 \\
.0078413 \\
8.33 e+07 \\
1.240188 \\
-1.017962 \\
-6.58 \mathrm{e}+08 \\
-1.39 \mathrm{e}+09 \\
2.77 \mathrm{e}+12\end{array}$ & $\begin{array}{l}.0033559 \\
.0118293 \\
.144463 \\
3.87 \mathrm{e}+08 \\
.1851832 \\
.1523556 \\
4.10 \mathrm{e}+08 \\
2.27 \mathrm{e}+08 \\
4.57 \mathrm{e}+11\end{array}$ & $\begin{array}{r}-1.25 \\
0.94 \\
0.05 \\
0.22 \\
6.70 \\
-6.68 \\
-1.60 \\
-6.12 \\
6.06\end{array}$ & $\begin{array}{l}0.213 \\
0.349 \\
0.957 \\
0.830 \\
0.000 \\
0.000 \\
0.109 \\
0.000 \\
0.000\end{array}$ & $\begin{array}{r}-.0107604 \\
-.0121011 \\
-.275301 \\
-6.76 \mathrm{e}+08 \\
-8772361 \\
-1.316573 \\
-1.46 \mathrm{e}+09 \\
-1.84 \mathrm{e}+09 \\
1.87 \mathrm{e}+12\end{array}$ & $\begin{array}{r}.0023946 \\
.0342689 \\
.2909836 \\
8.43 \mathrm{e}+08 \\
1.603141 \\
-.7193503 \\
1.46 \mathrm{e}+08 \\
-9.45 \mathrm{e}+08 \\
3.66 \mathrm{e}+12\end{array}$ \\
\hline $\begin{array}{r}\text { sigma_u } \\
\text { sigma_e } \\
\text { rho }\end{array}$ & $\begin{array}{r}0 \\
1.085 \mathrm{e}+10 \\
0\end{array}$ & (IT) & $v$ & e u & $\left.u_{-1}\right)$ & \\
\hline
\end{tabular}




\section{Note: Authors Compilations from STATA 13 \\ Note: The above random effects OLS result show results using panel data for Nigeria and the United States}

The generalized method of moment result using panel data for Nigeria and the United States is presented in table 4 . The results show that merchandise exports have strong positive significant effect on net trade (with p- values 0.000) contributing 77 percentage points to net trade growth, while merchandise imports have strong negative significant effect on net trade (with p-values 0.000 ). Net savings where found to have strong positive significant effect on net trade (with p-values 0.019 ) contributing 3 percentage points to net trade growth.

Table 4. Net Trade GMM Regression Result for Nigeria and the United States

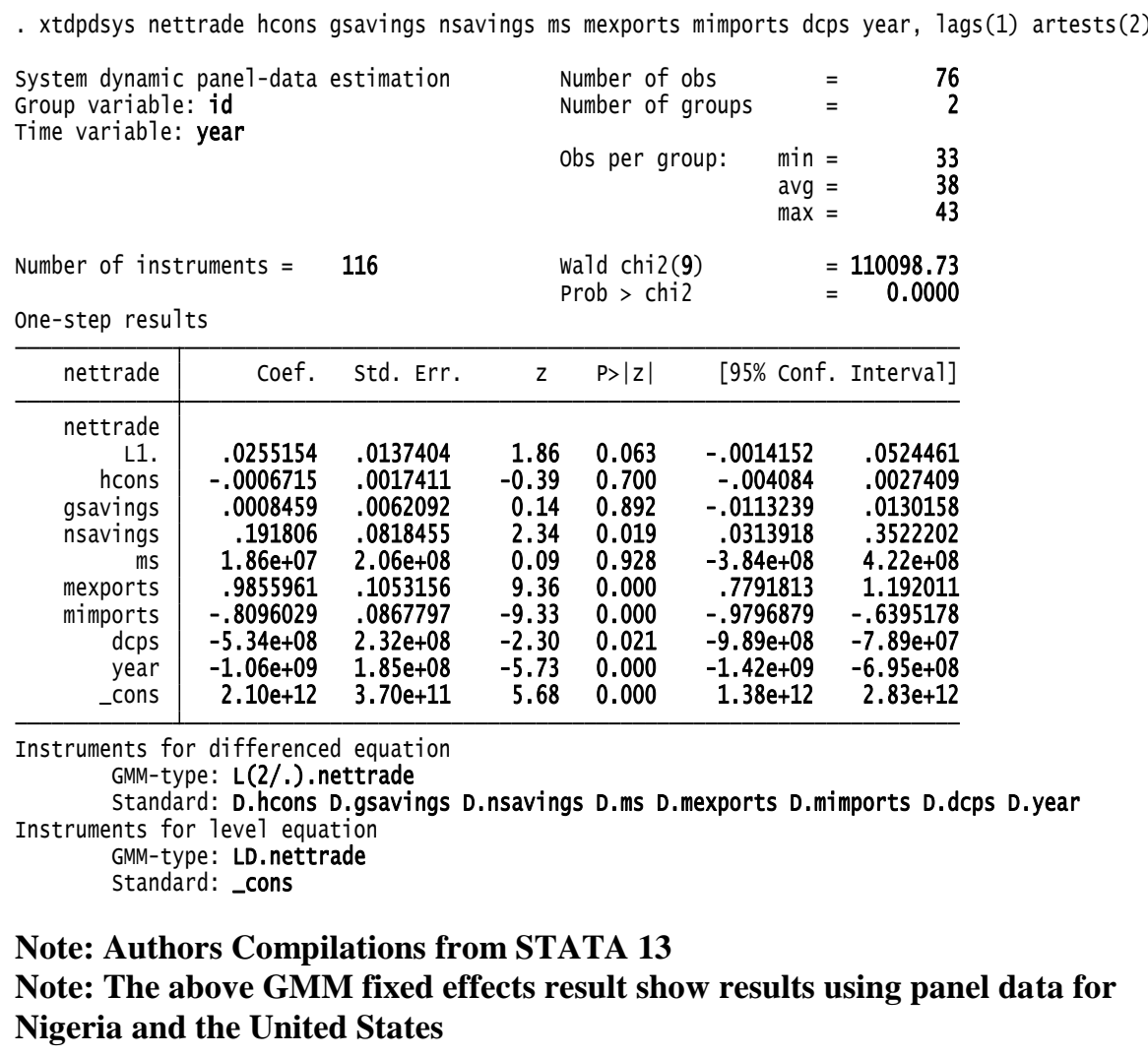

Direct capital to the private sector (dcps) have no significant effect on net trade improvement despite having a negative coefficient depicting its reducing capability on net trade growth, it is likely that firms were inappropriately apportioning loans to factors of production that could otherwise be sourced locally, in the purchase of such materials internationally. Country specific monetary policy captured using money supply (ms) were found not to impact net trade growth so also was household domestic consumption (hcons) depicting poor policy towards trade and consumption patterns that were promoting consumption of imports instead of domestic goods in both countries.

The questions posed in the early stage of the study are revisited. The questions, this study investigates includes what part of international merchandise trade is responsible for negative trade imbalance across countries? And secondly are other factors responsible for negative trade imbalance across countries? And finally what is the effect of net savings in countries on trade imbalance in general? It was found that the import component of merchandise trade is responsible for the negative and reducing effects on net trade causing negative trade imbalance across countries in the study, 
Secondly it was found that household domestic consumption and capital flow to private sector businesses had negative reducing effects of net trade but where however not significant, it was likely that consumers preferred foreign products due to issues of quality and taste to domestic products and it was also likely that producers in the private sector where utilizing a sizeable part of capital on purchase of foreign machineries and raw materials for further production. Thirdly, net savings were found to positively improve trade and were not responsible for negative trade imbalance and were responsible for positive trade balance for the United States specifically see table 2 and table 6 respectively.

\subsection{Discussion and Conclusion}

The study investigates the effect of entrepreneurial activity resulting from merchandise exports and imports on net trade using panel data for Nigeria and the United States on net trade with the aim to examine problems of trade imbalances. Entrepreneurial and trade activities in Nigeria and the United States were found to have strong consequences for both countries which were both positive and negative depending on specific conditions. Net savings was found to have strong positive implication for countries wishing to participate in international trade since it improves investor's perception of the trading country and improves its ability to stabilize it trade accounts in periods of negative trade or trade deficit, this was however only true for the United States since results for only Nigeria was not conclusively convincing with net savings having no significant effect on net trade for Nigeria see Tables 1 and 5.

Merchandise exports were also found to have a strong and positive effect on net trade improving trade balance in Nigeria and the United States. Domestic household consumption, Merchandise imports and capital flow to private entrepreneurs were found to have a negative effect on net trade. This was likely to be true since increases in household consumption of foreign products can increase imports, and it is likely that capital flows to private sector in both countries were used in sourcing raw materials and finished goods overseas forcing capital flows to the private sector to have negative effects on net trade causing trade imbalance across Nigeria and the United States.

In concluding the study, it was found that panel data can provide strong and convincing results in studying the relationship between trade imbalance and the nature of entrepreneurial activity resulting from trade for countries. This study for Nigeria and the United States show that merchandise exports was contributing 92 percentage points to trade growth in both countries (See Tables 4 and 6 respectively). Net national savings was found to be a major factor for trade stability in countries that wish to take strategic advantage of trade to improve economic growth in their respective countries.

Reducing imports particularly on commodities that are not important for further industrial production driven by domestic consumption was likely to make imports have strong positive effect on net trade. Policies that focus imports specifically on products that are necessary for further industrial activity is necessary for both countries and so also is the need for the improvement of exporting capabilities through the encouragement of entrepreneurial and industrial activity which is likely to have positive effects on exports and reduce trade deficit and trade imbalance for both countries.

\section{References}

[1] Arrelano M. and Bond S. (1998). "Dynamic Panel data estimation using DPD98 for Gauss: A guide for users"

[2] Cross K.H. (2004)" WTO Accession: Economic, Legal, and Political Implications" Boston College International and Comparative Law Review. 27(2), 319-370.

[3] Dollar D. (1992), "Outward - Oriented Developing Economies Really Do Grow More Rapidly: Evidence from 95 LDC's," 1976-1985, Economic Development and Cultural Change, 1992 (40), 523-544.

[4] Doornik, J.A., M. Arellano, and S. Bond.(2002),"Panel data estimation using DPD for Ox".

[5] Keller W. (2001)"Knowledge Spillovers at The World Technology Frontier" NBER Working Paper, $8150,2001$.

[6] Oh I.H., J.D Lee and A. Heshmati (2008)" Total Factor Productivity in Korean Manufacturing Industries," Global Economic Review. 37 (1), 23-50

[7] Roodman, D. (2006). How to Do xtabond2: "An introduction to "Difference" and "System" GMM in Stata". Working Paper 103, Center for Global Development, Washington.

http://dx.doi.org/10.19085/journal.sijbpg041101 
[8] Saggi K. (2000) "Trade Foreign Direct Investment and International Technology Transfer: A Survey," World Bank Policy Research Working Papers, No. 2349.

[9] Wagner (2007), "Exports and Productivity: A Survey of the Evidence from Firms Level Data." The World Economy, 30 (1), 60-82.

\section{Appendix I}

\section{Appendix}

Table 5. OLS Interpretation Table For Nigeria

\begin{tabular}{ll}
\hline VARIABLES & $(1)$ \\
& Net trade \\
\hline Household Consumption & 0.00107 \\
& $(0.0372)$ \\
Gross Savings & $-0.298^{*}$ \\
& $(0.167)$ \\
Net Savings & 0.102 \\
& $(0.195)$ \\
Money Supply & $4.092 \mathrm{e}+07$ \\
& $(3.397 \mathrm{e}+08)$ \\
Merchandise Exports & $0.819^{* * *}$ \\
& $(0.159)$ \\
Merchandise Imports & $-0.772^{* *}$ \\
& $(0.306)$ \\
Direct Capital to Private Sector & $-3.191 \mathrm{e}+07$ \\
& $(4.221 \mathrm{e}+08)$ \\
Fixed Effect & No \\
& \\
Observations & 33 \\
R-squared & 0.799 \\
\hline
\end{tabular}

Standard errors in parentheses*** $\mathrm{p}<0.01, * * \mathrm{p}<0.05, * \mathbf{p}<0.1$

Note: Authors Compilations from STATA 13

\section{Appendix II}

Table 6. All Net Trade Regressions for Nigeria and the United States

\begin{tabular}{llll}
\hline & $\begin{array}{l}(\mathbf{1}) \\
\text { OLS RE } \\
\text { Net trade }\end{array}$ & $\begin{array}{l}(\mathbf{2}) \\
\text { OLS FE } \\
\text { Net trade }\end{array}$ & $\begin{array}{l}\text { (3) } \\
\text { SYS. GMM } \\
\text { Net trade }\end{array}$ \\
\hline & & & $0.0260^{*}$ \\
L. Net trade & & & $(0.0143)$ \\
& & -0.00164 \\
Household consumption & $-0.00608^{*}$ & 0.00666 & $(0.00174)$ \\
Gross savings & $(0.00316)$ & $(0.00483)$ & 0.00285 \\
& 0.0152 & 0.00355 & $(0.00631)$ \\
Net savings & $(0.0115)$ & $(0.0113)$ & $0.253^{* * *}$ \\
& 0.0601 & 0.0798 & $(0.0837)$ \\
Money Supply & $(0.146)$ & $(0.136)$ & -1.29 \\
& -1.052 & -2.308 & $(8.530)$ \\
Merchandise Exports & $(1.393)$ & $(1.353)$ & $0.922^{* * * *}$ \\
& $1.187 * * *$ & $1.203 * * *$ & $(0.108)$ \\
Merchandise Imports & $(0.188)$ & $(0.176)$ & $-0.752^{* * *}$ \\
& $-0.966^{* * *}$ & $-0.989 * * *$ & $(0.0890)$ \\
Private Sector Capital Flow & $(0.154)$ & $(0.144)$ & $-4.246 \mathrm{e}+08$ \\
Fixed Effect Dummy & $-3.842 \mathrm{e}+09$ & $1.466 \mathrm{e}+10$ & $(6.807 \mathrm{e}+09)$ \\
Observations & $(1.033 \mathrm{e}+10)$ & $(1.113 \mathrm{e}+10)$ & Yes \\
R-squared & Yes & Yes & 76 \\
Number of id & 77 & 77 & 2 \\
\hline
\end{tabular}

Note: Standard errors in parentheses $* * * \mathbf{p}<0.01, * * \mathbf{p}<0.05, * \mathbf{p}<0.1$

Note: Authors Compilations from STATA 13

http://dx.doi.org/10.19085/journal.sijbpg041101 